研究論文

\title{
マテリアルリスク指標とその応用
}

\section{Materials-Risk-Index and Its Application}

\author{
芳須弘 ${ }^{1 *}$, 藤田充苗 ${ }^{2}$, 原田幸明 ${ }^{1}$, 緒形俊夫 ${ }^{1}$ \\ Hiroshi YOSHIZU $^{1 *}$, Mitsutane FUJITA ${ }^{2}$, Kohmei HALADA ${ }^{1}$ and Toshio OGATA ${ }^{1}$
}

\section{1 (独) 物質・材料研究機構}

National Institute for Materials Science

テ305-0047 茨城県つくば市千現 1-2-1

E-mail:YOSHIZU.Hiroshi@nims.go.jp

2 総合科学研究機構

Comprehensive Research Organization for Science and Society

T300-0811 茨城県土浦市上高津 1601 番地 筑波産学協同棟

原子力発電, 化学プラントなどの機器用材料の素材採集時の鉱石採掘などによって環境破 壊が生じる。また，それらの材料製造中に発生する CO2，SOx，およびNOx による大気污染 が地球環境に影響をおよぼす．地球環境を大きく変えない持続的社会を形成するために，機 器設計時の材料評価にマテリアルリスク指標が提案されている．その指標は，資源の持続的 供給，製造時の環境変動，そして毒性の 3 種類のリスクから成っており，それぞれのリスク に関係する因子の数值が示されている.

本報告では，これらの指標のデータ構造を決定した後，リスク指標のデータベースを試作 し，Web で提供されている耐熱材料の特性との関係を調べた。 その結果，地球環境を考慮し た機器設計時における最適材料は容易に入手可能な元素からなる材料を選択すべきとの方向 性を示した。その方向の妥当性について各種のステンレス鋼を評価し，ニッケルをマンガン で置き換えたステンレス鋼の環境適合性が良好なことを示した.

Environmental damage and deforestation occur frequently during ore mining to supply the resource of materials used for nuclear power generation and chemical plants. Further, the air pollution by $\mathrm{CO} 2$, SOx, and NOx generated in the production of those materials, affects on the global environment. In order to achieve the sustainable society that does not have a significant impact on the global environment, we have already proposed the material risk indexes which show the materials evaluation at the time of the apparatus design. The indexes consist of three kinds of risks, i.e. the sustainable supply of resources, environmental load during production of material, and toxicity of materials, and the numerical values related to the parameters of these risks were also shown. 
In this research, the construction of the database to store the information about three risk indexes was tried after the determination of data structure of the indexes. The relation between the risk indexes and the properties in the heat-resistant materials provided in the Web information was investigated As a result, based on the optimal environmental conformity, it was clarified that the materials selection for the apparatus using at high temperature should be directed toward the use of materials consisted mainly of easily obtainable atomic elements. The validity of the direction was estimated for various stainless steels and it is indicated that the stainless steel replaced $\mathrm{Ni}$ with Mn has a good value in the environmental conformity.

キーワード：持続可能社会, マテリアルリスク指標, 材料特性, 材料特性評価, 材料選択

Sustainable Society, Materials-Risk-Index, Materials Properties, Evaluation of Materials Properties,

\section{1 はじめに}

原子力発電, 化学プラントなどの金属系構 造物や機器用材料の資源となる鉱石採掘に よる自然破壊および材料の製造過程で排出 される $\mathrm{CO} 2, \mathrm{SOx}$ および NOx による大気污 染が地球環境に影響を及ぼしている. 地球環 境を大きく変えない持続的社会を達成する ためには, 構造物や機器用材料の選択を, 従 来の材料特性や経済性の観点からの他に資 源の持続供給可能性, 製造過程での環境変動, 材料の毒性などの環境適合性に対する考慮 が要求される。これまで, エコマテリアルの 観点から材料設計・選択に関する提案がなさ れており, さらに, 機器設計時の材料評価, 選択の方向性を示すマテリアル指標 （Materials Risk Index）が（独）物質・材料 研究機構（以下, 物材機構と略）の原田らに より提案されている[1]. この提案では, 地 球環境問題を考慮した持続可能な社会の形 成のための環境材料評価基準となる環境適 合性を数值化したマテリアルリスク指標と して, 資源の持続的供給, 環境変動, そして 毒性の 3 種類のリスクについて調査が進め
られており, 合金元素に関して概算されたリ スク係数などが示されている $[1,2]$.

マテリアルリスク指標[1]を考慮した材料 評価は, 同一の特性を持つならばより地球環 境に負荷をかけない, より環境適合性を意識 した材料を選択すべきである. 著者らは持続 的社会を考慮した材料選択を，環境適合性と 材料特性の両者を連携した材料評価を検討 してきた[3,4,5].

本研究では，マテリアルリスク指標の 3 種類のリスクの因子であるデータ項目を検 討し, データ構造を決定し，それらをXML での記述を検討し, リスク指標データベース

（以下，データベースを DB と略）を試作し た.さらに, Web で提供されている耐熱材 料の特性との関係を調べた. マテリアルリス ク指標を種々の材料について算出し, その数 值とそれぞれの材料特性との関係を調べ, 材 料資源の持続供給性, 環境変動および毒性を 考慮した材料評価, 最適材料選択の方向性を 示す.

\section{2 マテリアルリスク指標}

図 1 は, 金属材料の環境適合性を表すマテ 


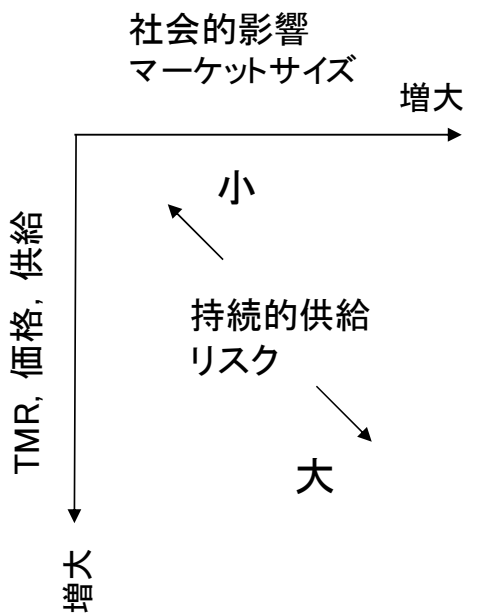

持続的供給リスク

材料の資源に関する影響
社会的影響

マーケットサイズ

増大

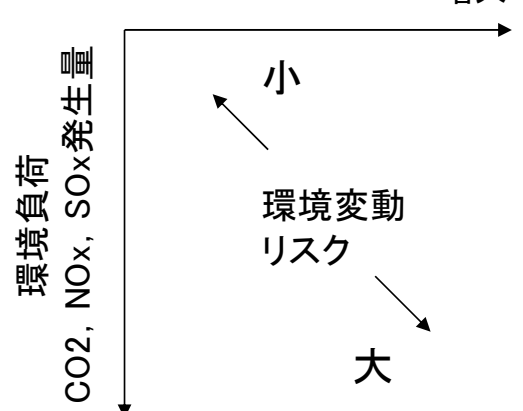

環境変動リスク

材料製造時における影響
社会的影響

暴露

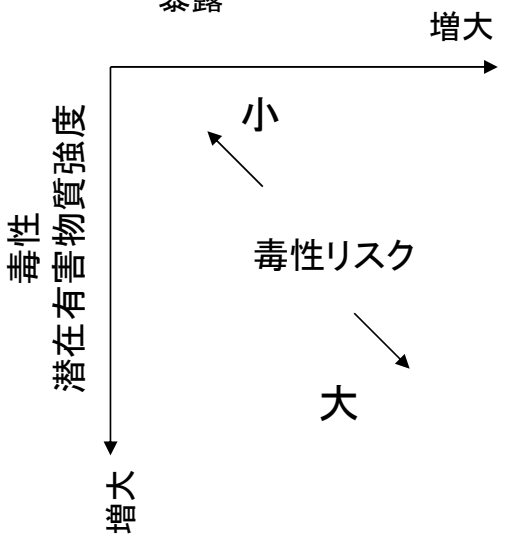

毒性リスク

材料使用時における影響

図 1 マテリアルリスク指標の概念図

リアルリスク指標の概念図を示す.この指標 は, 材料を製造し廃棄するまでの地球環境へ の影響度合いを示す. 指標は資源の持続的供 給, 環境変動および毒性の 3 種類のリスクか ら成り，各リスクは，それぞれに関係する縦 軸の因子（データ項目）と横軸の社会的影響 などで表される.しかし, 社会的影響は物質 の生産量／消費量が考えられるが, 数值とし て示すのは容易でないので,ここでは各リス クに関係する因子の種々の合金元素につい ての数值を用いて, 金属材料の持続的社会へ の環境適合性の度合いを示すことにする。ま た, 各リスクの因子は 1 個ではなく, 次節の ように複数考えられている.

\section{1 マテリアルリスク指標に関する情報}

3 種類のリスクに関係する因子について以 下に述べる.これらの因子をデータ項目とし， その数值を格納したマテリアルリスク指標 のDB化によって材料の環境適合性の評価が 可能になる.

\subsection{1 持続的供給リスク}

持続的供給リスクは, 主な記述項目として,

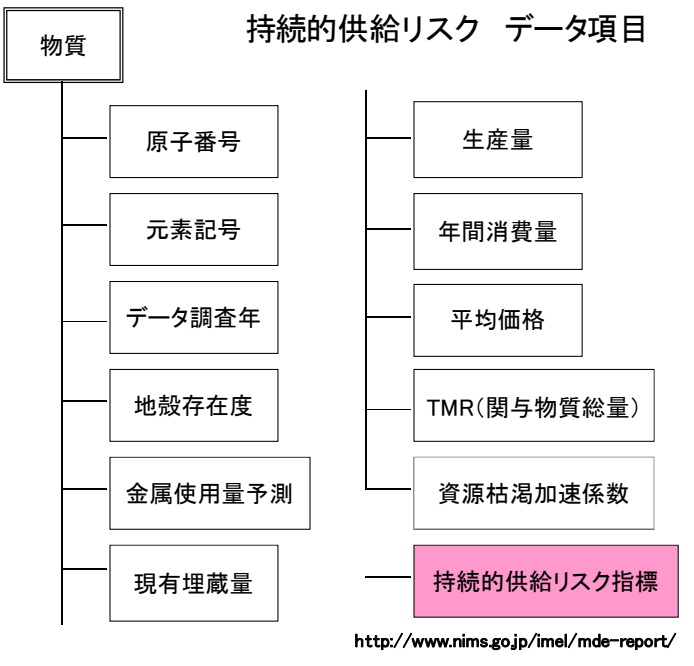

図 2 持続的供給リスクのデータ項目

図 2 に示したような項目が挙げられる.この リスクでは，物質（資源）をルートとして， その下位に埋蔵量, 生産量あるいは年間消費 量などの物質量に関する項目やその物質の 生産に関与寸る TMR がある.TMR とは, 関 与物質総量 (製造に関与する物質の総量であ り,Total Material Requirement, 以下, TMR と 略）[6]である。TMR は，次節の材料製造時 の環境変動リスクの 1 つの因子でもあり詳 細は次節で示す。また，資源消費に関するデ 一夕項目として耐用年数, 資源枯渇加速係数 
があり，資源の市場価格（平均価格）や年間 の生産量や消費量によって, 以下の式 (抜粋) により導き出される[2,4,7].

資源の耐用年数 $=$ 資源の埋蔵量 $/$ 資源の消 費量

年間資源枯渇加速度 $=$ 年間生産量 $\times$ 資源枯 渇加速度

さらに, 価格の安定性と資源の国による遍 在性から導かれる供給リスクも提案されて いる[1]. これらのデータ項目の数值データ

(係数)により物質の持続的供給リスクが算 出できる。

\subsection{2 環境変動リスク}

図 3 は, 環境変動リスクの情報に関するデ ータ項目を示す.ここでは材料をルートとし て, 各データ項目には材料を構成する成分 （合金元素など）を記述し，材料の製造法や 製造時に発生する $\mathrm{CO} 2$ などの発生量を環境 負荷データとして記述し,さらに製造時の水 使用量や水質污染などの環境に関わるデー 夕を記述する．また，材料を構成する成分の 採掘から製造, 使用そして廃棄までのエネル ギーの流れを物量フロー，TMR フローとし て記述する。 TMR フローとは, 式 : $\mathrm{M}_{\mathrm{TMR}}$ $=\Sigma \mathrm{M}_{\mathrm{DI}(\mathrm{i})}+\sum \mathrm{M}_{\mathrm{II}(\mathrm{i})}+\sum \mathrm{M}_{\mathrm{HF}(\mathrm{i})}$ で定義さ れ， $\sum \mathrm{M}_{\mathrm{DI}(\mathrm{i})}$ は直接物質投入量を， $\sum \mathrm{M}_{\mathrm{II}(\mathrm{i})}$ は 間接物質投入量を， $\Sigma \mathrm{M}_{\mathrm{HF}(\mathrm{i})}$ は隠れた物質フ ロー量を表す。

直接および間接物質投入量は, 人間の経済 的行為として直接的にもしくは間接的に投 入された物質の量である. 隠れた物質フロー 量は, 直接的および間接的な経済行為にとも なって起こる物質の移動量や採掘などに必 要とされる水を含めた水系, さらに土地の再 生, 景観の保護に必要な物質の総量も含まれ る[3].これらの情報により環境変動リスク を算定する。

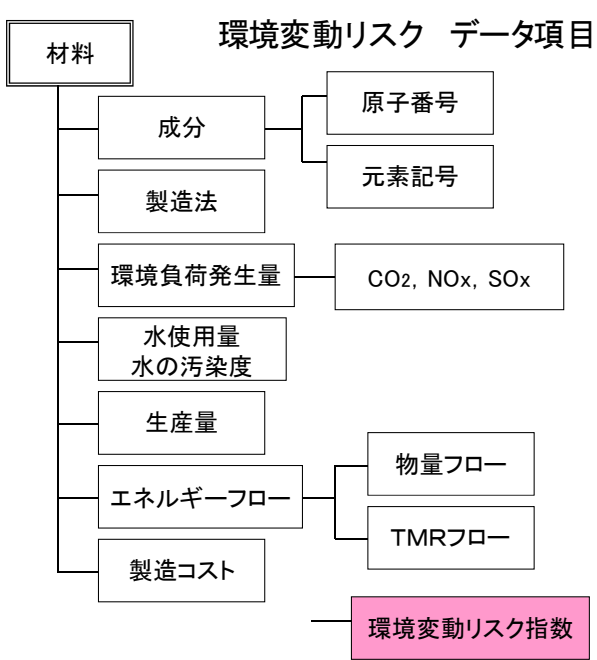

図 3 環境変動リスクのデータ項目

ここで，材料は，ニッケル，クロム，モリ ブデンなど様々な合金元素により構成され ているが，これらの合金元素はフェロアロイ の形で添加され，合金化される，材料の製造 には原材料の溶解から精錬など様々な工程 を経て製品となるが，各工程では大気污染物 質や機器から排出される排気ガスなどが発 生する[8].

以下の材料の環境負荷算出については, 物 材機構の環境負荷データベースシステム[9] を用いた。また，同機構のクリープデータシ 一ト 41 鋼種[10]の材料の主要成分から算出 した発生量と炭素, 硫黄およびリンなどの不 純物の成分調整にともなう発生量を算出し, 積算した数值をデータとした. 環境負荷の算 定式については, 合金 1 トンあたりの材料を 電気炉などで溶解, 精鍊などを行う製造工程 の環境負荷值を算定する式が紹介[11]されて いる.

\section{1 .3 毒性リスク}

毒性リスクは, 対象となる物質をルートと して, 対象物質が単一の化学物質の場合と製 品に含有されている場合に分類して記述す る. 図 4 は毒性リスクに記述するべくデータ 
項目を示す.図に示したデータ項目は,

MSDS（物質安全データシート， Material Safety Data Sheet）と呼ばれ，国内規格とし て JIS Z 7250，国際規格として ISO11014-1 にその記載内容が標準化されており，この MSDS の記載内容から参照した[12,13].

MSDSをもとにした毒性リスクに記述す るデータ項目は, 単一, 製品に共通する項目 として物質の名称, 政令上の号番号, そして 物質の種類を記述し, 製品の場合はその物質 の含有率を記述する。これらの情報から潜在 有害物質強度とともに毒性リスクを算出す る。表 1 は，参考文献[14]より引用した各合 金元素の CO2，TMR そして毒性に関するリ スク係数（cell toxicity）を示す.

表 1 の毒性リスク係数は, 金属イオンの細 胞毒性を示す IC50 により算出された数值で ある。ここで，IC50とは金属イオンが MC3T3-E1（マウス頭蓋骨から樹立された骨

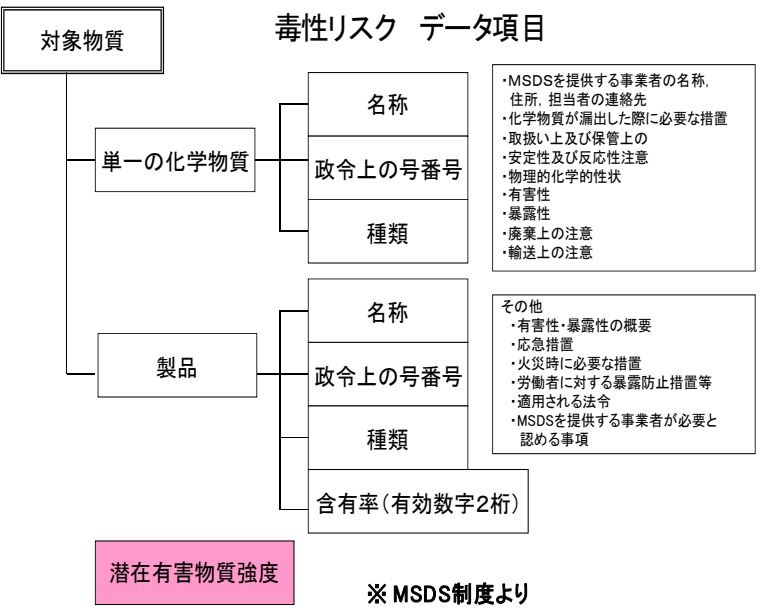

図 4 毒性リスクのデータ項目

芽細胞）や L929（マウスの線維芽細胞）な どの細胞に対して 50\%の阻害率 (生体の活性 を 50\%に低下させる）を示すものであり，毒 性の強さを表す指標として用いられている [15].また，毒性リスクの単位は mg/L（重量 /容量）であり，水中に含まれる物質の濃度 を示すものである。

表 1 各合金元素の毒性リスク係数

\begin{tabular}{|c|c|c|c|c|}
\hline No. & Element & $\begin{array}{c}\mathrm{CO} 2 \\
\mathrm{tCO} 2 / \mathrm{tMetal}\end{array}$ & $\begin{array}{l}\text { TMR } \\
-/-\end{array}$ & $\begin{array}{c}\text { cell toxicity } \\
(\mathrm{mg} / \mathrm{L})\end{array}$ \\
\hline 3 & $\mathrm{Li}$ & $1.90 \mathrm{E}+01$ & $1.50 \mathrm{E}+03$ & $9.50 \mathrm{E}+04$ \\
\hline 4 & $\mathrm{Be}$ & $7.40 \mathrm{E}+01$ & $2.50 \mathrm{E}+03$ & $1.30 \mathrm{E}+02$ \\
\hline 13 & $\mathrm{Al}$ & $9.20 \mathrm{E}+00$ & $4.80 \mathrm{E}+01$ & $9.40 \mathrm{E}+04$ \\
\hline 22 & $\mathrm{Ti}$ & $6.90 \mathrm{E}+00$ & $3.60 \mathrm{E}+01$ & $4.70 \mathrm{E}+04$ \\
\hline 23 & $\mathrm{~V}$ & $2.50 \mathrm{E}+01$ & $1.50 \mathrm{E}+03$ & $1.30 \mathrm{E}+02$ \\
\hline 24 & $\mathrm{Cr}$ & $7.90 \mathrm{E}+00$ & $2.60 \mathrm{E}+01$ & $2.00 \mathrm{E}+02$ \\
\hline 25 & $\mathrm{Mn}$ & $2.80 \mathrm{E}+00$ & $1.40 \mathrm{E}+01$ & $2.30 \mathrm{E}+03$ \\
\hline 26 & $\mathrm{Fe}$ & $8.40 \mathrm{E}-01$ & $8.20 \mathrm{E}+00$ & $7.40 \mathrm{E}+04$ \\
\hline 27 & Co & $1.50 \mathrm{E}+01$ & $6.10 \mathrm{E}+02$ & $1.80 \mathrm{E}+03$ \\
\hline 28 & $\mathrm{Ni}$ & $8.20 \mathrm{E}+00$ & $2.60 \mathrm{E}+02$ & $4.40 \mathrm{E}+03$ \\
\hline 29 & $\mathrm{Cu}$ & $3.50 \mathrm{E}+00$ & $3.60 \mathrm{E}+02$ & $1.60 \mathrm{E}+03$ \\
\hline 30 & $\mathrm{Zn}$ & $2.80 \mathrm{E}+00$ & $3.60 \mathrm{E}+01$ & $6.00 \mathrm{E}+03$ \\
\hline 31 & $\mathrm{Ga}$ & $2.60 \mathrm{E}+01$ & $7.30 \mathrm{E}+03$ & $2.10 \mathrm{E}+03$ \\
\hline 37 & $\mathrm{Rb}$ & $1.90 \mathrm{E}+00$ & $1.30 \mathrm{E}+02$ & $3.00 \mathrm{E}+05$ \\
\hline 38 & $\mathrm{Sr}$ & $7.90 \mathrm{E}+00$ & $5.20 \mathrm{E}+02$ & $3.10 \mathrm{E}+05$ \\
\hline 39 & $\mathrm{Y}$ & $1.10 \mathrm{E}+01$ & $2.70 \mathrm{E}+03$ & $5.30 \mathrm{E}+03$ \\
\hline 40 & $\mathrm{Zr}$ & $2.50 \mathrm{E}+00$ & $5.50 \mathrm{E}+02$ & $2.00 \mathrm{E}+05$ \\
\hline 41 & $\mathrm{Nb}$ & $2.40 \mathrm{E}+01$ & $6.40 \mathrm{E}+02$ & $2.10 \mathrm{E}+05$ \\
\hline 42 & Mo & $1.50 \mathrm{E}+01$ & $7.50 \mathrm{E}+02$ & $2.00 \mathrm{E}+05$ \\
\hline 44 & $\mathrm{Ru}$ & $1.60 \mathrm{E}+02$ & $7.90 \mathrm{E}+04$ & $2.40 \mathrm{E}+05$ \\
\hline 45 & $\mathrm{Rh}$ & $1.10 \mathrm{E}+03$ & $2.30 \mathrm{E}+06$ & $2.50 \mathrm{E}+03$ \\
\hline 46 & $\mathrm{Pd}$ & $3.30 \mathrm{E}+02$ & $8.10 \mathrm{E}+05$ & $3.30 \mathrm{E}+04$ \\
\hline 47 & $\mathrm{Ag}$ & $4.50 \mathrm{E}+00$ & $4.80 \mathrm{E}+03$ & $3.70 \mathrm{E}+02$ \\
\hline 48 & $\mathrm{Cd}$ & $4.10 \mathrm{E}+00$ & $6.80 \mathrm{E}+01$ & $2.10 \mathrm{E}+02$ \\
\hline 49 & In & $2.30 \mathrm{E}+00$ & $1.20 \mathrm{E}+04$ & $2.00 \mathrm{E}+02$ \\
\hline 50 & Sn & $5.10 \mathrm{E}+00$ & $2.50 \mathrm{E}+03$ & $7.00 \mathrm{E}+03$ \\
\hline 51 & $\mathrm{Sb}$ & $5.20 \mathrm{E}-01$ & $5.60 \mathrm{E}+01$ & $7.90 \mathrm{E}+02$ \\
\hline 56 & $\mathrm{Ba}$ & $4.60 \mathrm{E}+00$ & $5.10 \mathrm{E}+02$ & $2.20 \mathrm{E}+05$ \\
\hline 72 & $\mathrm{Hf}$ & $1.30 \mathrm{E}+01$ & $6.80 \mathrm{E}+03$ & $2.20 \mathrm{E}+05$ \\
\hline 73 & $\mathrm{Ta}$ & $1.60 \mathrm{E}+01$ & $1.90 \mathrm{E}+02$ & $3.60 \mathrm{E}+05$ \\
\hline 74 & W & $1.90 \mathrm{E}+00$ & $1.80 \mathrm{E}+04$ & $8.50 \mathrm{E}+04$ \\
\hline 77 & Ir & $3.90 \mathrm{E}+02$ & $4.00 \mathrm{E}+05$ & $3.30 \mathrm{E}+03$ \\
\hline 81 & TI & $1.30 \mathrm{E}+01$ & $4.30 \mathrm{E}+02$ & $5.90 \mathrm{E}+03$ \\
\hline 82 & $\mathrm{~Pb}$ & $3.40 \mathrm{E}+00$ & $2.80 \mathrm{E}+01$ & $2.70 \mathrm{E}+04$ \\
\hline 83 & $\mathrm{Bi}$ & $5.30 \mathrm{E}-01$ & $2.20 \mathrm{E}+02$ & $2.00 \mathrm{E}+04$ \\
\hline
\end{tabular}

\section{主要合金元素の抜粋}

\begin{tabular}{|c|c|c|c|c|}
\hline No. & Element & $\begin{array}{c}\mathrm{CO} 2 \\
\text { tCO2/tMetal }\end{array}$ & $\begin{array}{c}\text { TMR } \\
-/-\end{array}$ & $\begin{array}{c}\text { cell toxicity } \\
(\mathrm{mg} / \mathrm{L})\end{array}$ \\
\hline 13 & $\mathrm{Al}$ & $9.20 \mathrm{E}+00$ & $4.80 \mathrm{E}+01$ & $9.40 \mathrm{E}+04$ \\
\hline 22 & $\mathrm{Ti}$ & $6.90 \mathrm{E}+00$ & $3.60 \mathrm{E}+01$ & $4.70 \mathrm{E}+04$ \\
\hline 23 & $\mathrm{~V}$ & $2.50 \mathrm{E}+01$ & $1.50 \mathrm{E}+03$ & $1.30 \mathrm{E}+02$ \\
\hline 24 & $\mathrm{Cr}$ & $7.90 \mathrm{E}+00$ & $2.60 \mathrm{E}+01$ & $2.00 \mathrm{E}+02$ \\
\hline 25 & $\mathrm{Mn}$ & $2.80 \mathrm{E}+00$ & $1.40 \mathrm{E}+01$ & $2.30 \mathrm{E}+03$ \\
\hline 26 & $\mathrm{Fe}$ & $8.40 \mathrm{E}-01$ & $8.20 \mathrm{E}+00$ & $7.40 \mathrm{E}+04$ \\
\hline 27 & $\mathrm{Co}$ & $1.50 \mathrm{E}+01$ & $6.10 \mathrm{E}+02$ & $1.80 \mathrm{E}+03$ \\
\hline 28 & $\mathrm{Ni}$ & $8.20 \mathrm{E}+00$ & $2.60 \mathrm{E}+02$ & $4.40 \mathrm{E}+03$ \\
\hline 41 & $\mathrm{Nb}$ & $2.40 \mathrm{E}+01$ & $6.40 \mathrm{E}+02$ & $2.10 \mathrm{E}+05$ \\
\hline 42 & $\mathrm{Mo}$ & $1.50 \mathrm{E}+01$ & $7.50 \mathrm{E}+02$ & $2.00 \mathrm{E}+05$ \\
\hline 73 & $\mathrm{Ta}$ & $1.60 \mathrm{E}+01$ & $1.90 \mathrm{E}+02$ & $3.60 \mathrm{E}+05$ \\
\hline 74 & $\mathrm{~W}$ & $1.90 \mathrm{E}+00$ & $1.80 \mathrm{E}+04$ & $8.50 \mathrm{E}+04$ \\
\hline
\end{tabular}


本研究ではこの表から材料の主要合金元 素（表 1 右）を抜粋してその添加量と毒性リ スク係数により算出し, 持続的供給リスクな どと同様に材料の高温特性との関係を調べ た。ここで，毒性リスクは，IC50 と同一で はなく，IC50をもとにして算出されたリス ク係数（表 1 左右とも一番右側）により算出 した数值を毒性リスクとした。これを係数と して材料 1 トンに対して主要合金元素を基 に算出したが，以下の結果等については，合 金元素の添加量をリスク係数によりノーマ ライズし，積算したものであり，本来は各合 金元素が金属イオンあるいは金属塩状態に あるときの毒性に注目すべきであることを 記しておく。

各リスクのデータ構造を検討することよ り，指標に関係する情報を網羅的に収集・整
理が可能になる.

\section{2 材料の各リスクの算出}

ここでは前述した情報をもとに, 各材料に ついて各リスクの数值を算出し, その結果を 示す.

\subsection{1 持続的供給リスク}

図 5 は各材料について持続的供給リスク の社会的影響度の指標となる TMR，価格お よび供給について算出した結果を合金系に 分類して示す．数值算出には参考文献 $[2,6]$ より各合金元素について算出されている数 值を係数として引用し, 各材料の主要合金元 素について計算し，その数值を積算して示し た。図 5 は，本報告で用いた材料 41 鋼種を 示しているが，各材料は規格（例えば，JIS 規格）が同じでも規格の範囲内で成分調整さ

材料1トンの持続的供給リスク

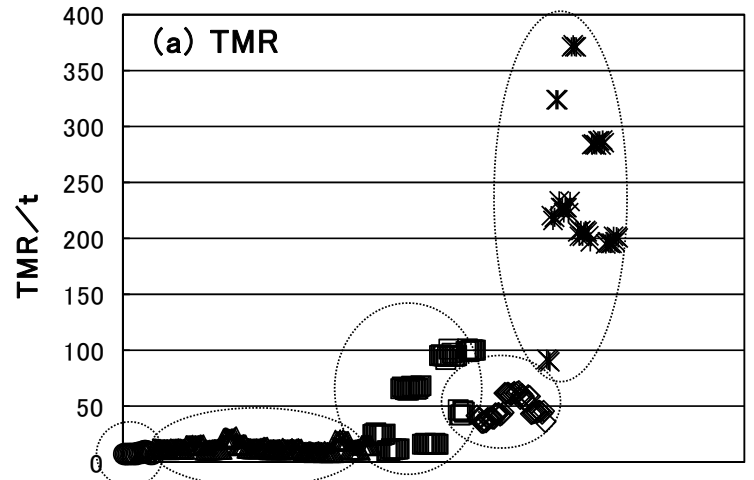

材料 (合金系による分類)

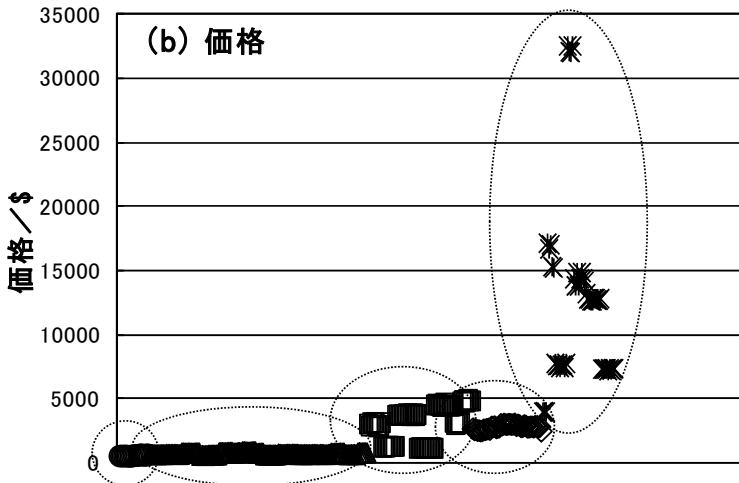

材料(合金系による分類)

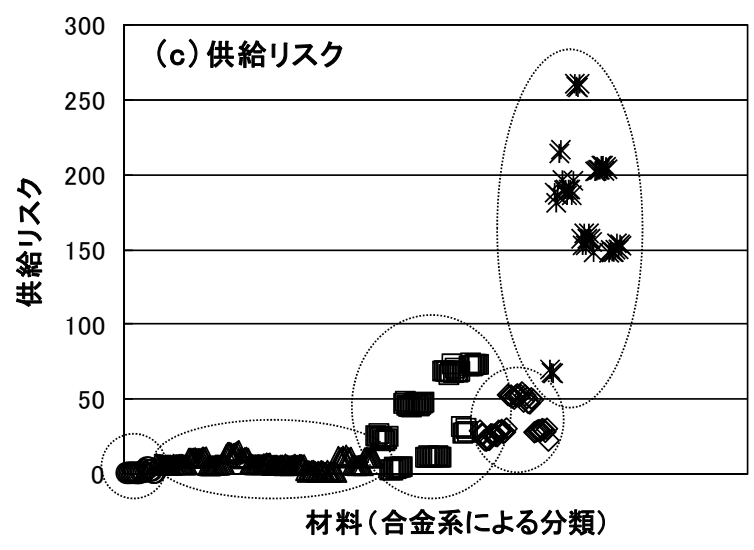

図 5 材料の持続的供給リスク
○炭素鋼

$\Delta$ 低合金鋼

口高合金鋼

๖ステンレス鋼

* 超合金 
れているため複数のヒート(ロット)があり, その数は 300 を超える.また，この図は各 材料（41 鋼種）を合金系別に分類して各材 料の各リスクを概観することを目的とした。

\section{TMR}

図 5(a)は各材料 1 トン当りについて算出し た TMR を示す，縦軸に TMR，横軸に合金系 により分類した各材料を示す．シンボルは， $\bigcirc$ : 炭素鋼, $\triangle$ : 低合金鋼, $\square$ : 高合金鋼, $\diamond:$ ステンレス鋼, そして*:超合金である。

図 5(a)の結果から各合金系の TMR は，鉄が 多くを占める炭素鋼や低合金鋼は TMR が少 ないが, ニッケルやモリブデンなどの添加合 金元素の種類の数やその添加量が多い超合 金ほど多くなっている. 超合金については材 料のベースとなる金属により TMR 量の差が 大きくなってばらついている.

\section{価格}

図 5(b)は各材料の 1 トン当りの価格を示す。 価格については安価な鉄が多くを占める炭 素鋼や低合金鋼は積算した総価格が安くな っているが, 超合金のようにニッケルやモリ ブデンなどの添加合金元素の種類の数やそ の添加量により高価なものになっている.ま た，超合金の中でも特に高価な值を示してい る材料はベースとなる金属が高価なコバル トであることが起因する。

\section{供給リスク}

図 5(c)は材料 1 トン当りの供給リスクを 示す. 材料の供給リスクについてもその傾 向として炭素鋼は低く, 超合金では炭素鋼 に比べて供給リスクが著しく高くなってい ることがわかる。これは炭素鋼や低合金鋼 などはべースが鉄であり，鉄は埋蔵量も多 く，またリサイクルなどで再利用されるこ とも起因してリスクが低くなっている。こ れに対して埋蔵量が少ない合金元素を多く
含有する材料は供給リスクも高くなる.

\subsection{2 環境変動リスク 各合金元素の環境負荷}

主要合金元素の製造工程において使用す るエネルギーを含めて, 各工程で排出される 環境負荷についてその発生量が関係サイト [16]で紹介されている，また，合金元素を製 造する際の環境負荷については物材機構の 原田らにより求められ，DB として公開され ている[9]. また，各合金元素の環境負荷も 公開されており,その結果では環境負荷の発 生量はいずれもニッケルが他の合金元素に 比べて多い結果となっている.これはニッケ ル抽出のための精鍊工程が大きく影響して いる.

各種の合金元素について環境負荷が概算 されているが, 材料はこれらの合金元素によ り構成されており，図６は各材料を合金系に より分類してそれぞれの環境負荷 ( $\mathrm{CO} 2$ のみ 抜粋）を示す．SOx 及び NOx についても同 様な傾向を示したので省略する. 図 6 は 41 種類の材料を同じく合金系により分類して その環境負荷を示したが，炭素鋼，低合金鋼 は低く, やはり合金元素の種類や添加量の多 さにより高合金鋼，ステンレス鋼，そして超

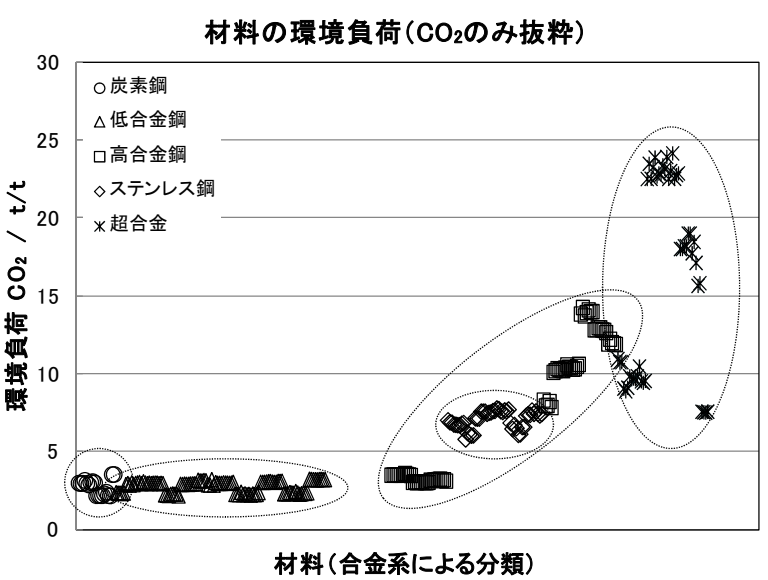

図 6 材料の環境負荷（CO2 のみ抜粋） 
合金はかなりの負荷を与えていることがわ かる.これは炭素鋼を構成する添加合金元素 のほとんどが環境負荷の低い鉄であり, 合金 元素の種類も少なく, 低合金鋼以下, 添加す る合金元素の種類が多くなり, 同時に公表さ れている各合金元素の環境負荷が加算され ることに起因する。また，超合金のばらつき は環境負荷の発生量が多いニッケルやモリ ブデンなどの量が影響している.

\subsection{3 毒性リスク}

図 7 は合金系により分類した材料の毒性 リスクを示す. 他のリスクと同様な傾向を示 しているが，これは他のリスクでも述べたよ うに合金元素の数の多さ, 添加量が起因する. さらに, 六価クロムに代表されるような毒性 を持ち, リスク係数も小さい（係数が小さい ほど合金元素の添加量が影響する) クロムも リスクを高くする要因のひとつである.

リスク指標 DB を試作することによって， 材料組成と連携すると, 合金の種類別のグラ フが容易に描くことができる.

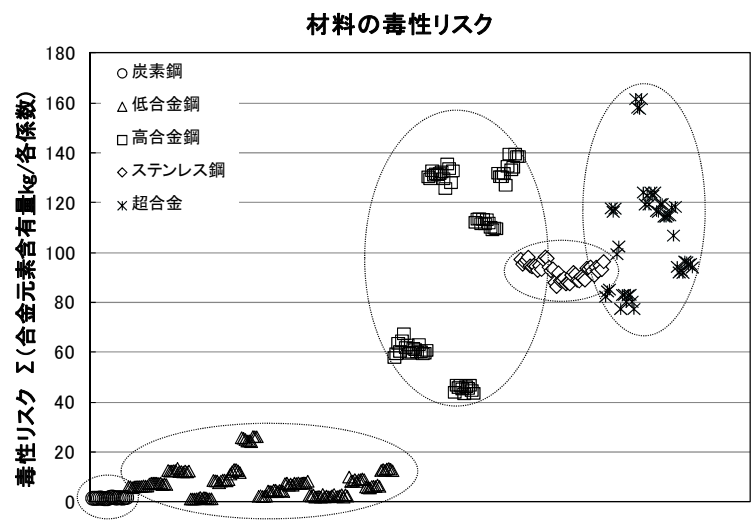

材料（合金系による分類）

図 7 材料の毒性リスク

\section{3 耐熱材料の特性}

材料特性に関するデータ項目は, 第 3 章で 後述する (図 9). 地球環境を考慮した評価, あるいは前述したマテリアルリスク指標の 応用については, 高温機器用材料の選択に必 要な高温特性とし，これまでにマテリアルリ スク指標を加えた評価を行っている[17].

材料特性の情報として, 物材機構クリープ データシート 41 鋼種の高温引張データと 10 万時間を超えるクリープ破断データを参照,

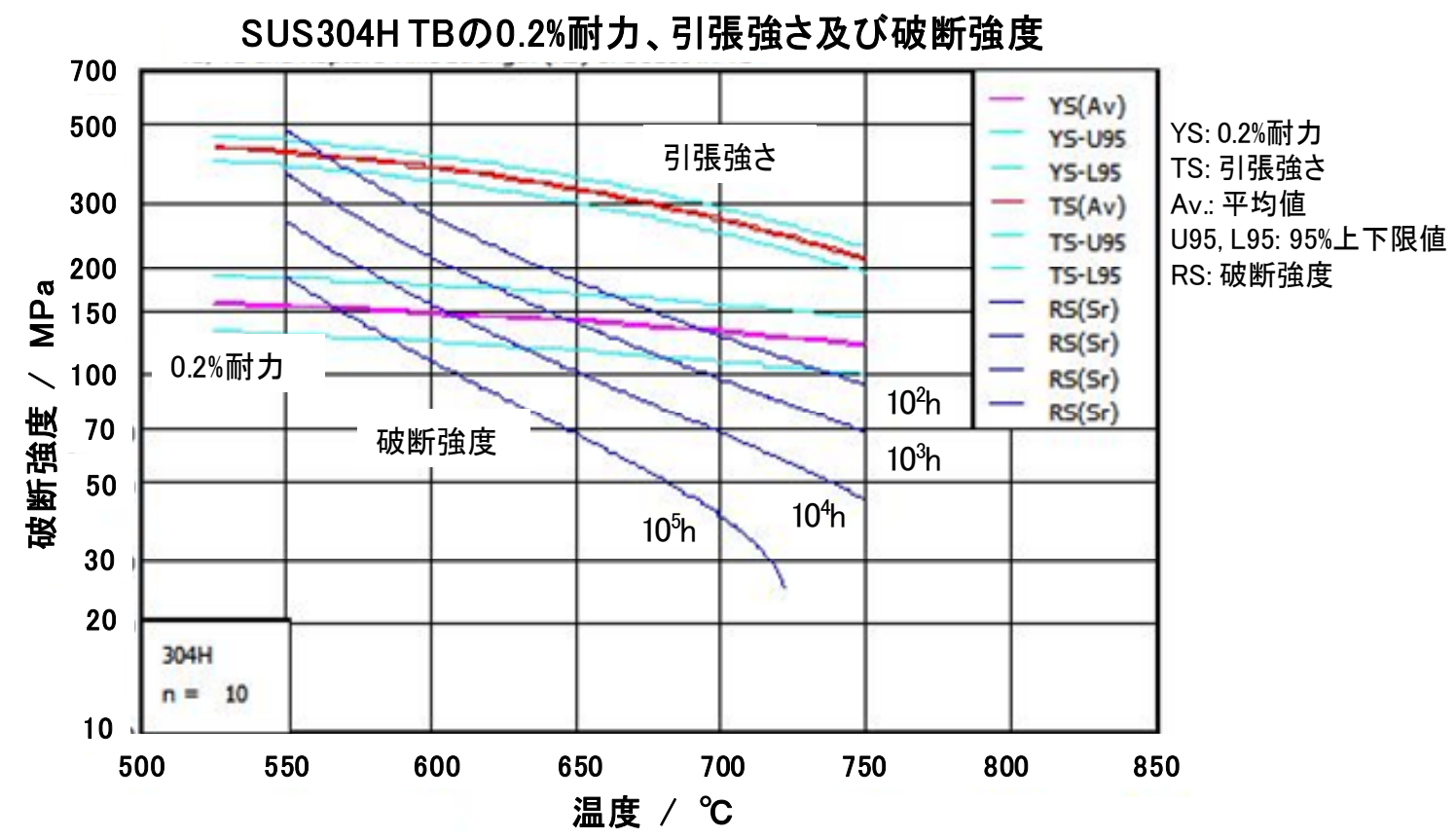

図 8 材料の高温特性を示す回帰曲線群（設計線図） 
解析し, 解析データとして評価に用いた. 図 8 は, 高温引張, クリープ破断データを解析 した例（設計線図）を示す。この例は，材料 の許容応力算出に必要な高温強度の温度依 存性をみる曲線群を示す。短時間強度である $0.2 \%$ 耐力および引張強さは, 温度の多項式 回帰により解析した結果を回帰曲線で示す. 太線が平均值，細線（淡色）が 95\%予測区 間（95\%予測区間とは，最小二乗法などの統 計的手続きにより回帰式を求めたものと同 じ母集団から新しく 1 個のサンプルを採つ たときに, 実現值がこの值の範囲に収まる確 率 95\%以上であることを保証できる限界值 である）の上下限值を示す。

長時間強度（以下，10 万時間強度）は Larson-Miller パラメータ法により内外挿（推 定）した結果をもとに 100 時間から 10 万時 間までの回帰曲線（等時クリープ破断曲線） を示す。この曲線群から例として， $650^{\circ} \mathrm{C}$, 10 万時間の破断強度は約 $70 \mathrm{MPa}$ であること がわかる。これらの回帰曲線群は，材料の許 容応力算出のための尺度となる.また, 解析 データとして条件を指定（応力：100MPa, 破断時間 : 10 万時間としたときの推定温度 $\left({ }^{\circ} \mathrm{C}\right)$ である）したデータもこの図から算出 した. さらに，各材料の 10 万時間強度の温 度依存性をみる等時クリープ破断曲線群 (図 8 の 10 万時間の破断強度を各材料について 抜粋して曲線群としたもの）を描き，その結 果, 材料は実機の使用環境により低温域の炭 素鋼から高温域の超合金まで幅広く分布す る.これらの結果は材料選択のためのひとつ の目安となる。

\section{3 マテリアルリスク指標の応用}

マテリアルリスク指標と材料特性を結び 付ける手順についてXML 記述法を用いて指
標 DBのデータ構造の検討と試作について以 下に述べる。

\section{1 各リスクと材料特性のデータ項目 3.1.1 各リスクのデータ項目}

マテリアルリスク指標の持続供給, 環境変 動および毒性の各リスクのルートとなる項 目は，物質 (対象物質)，材料である。物質 は単体あるいは製品であり, 単体では材料を 構成する鉄やニッケルなどの合金元素も含 まれるので結び付ける項目となる.

\section{1 .2 材料特性のデータ項目}

材料特性のデータ項目は, 図 9 に示したよ うにデータ共有に関する汎用的な材料DB記 述のための枠組みである MatML (図左) [18] をもとにし，その MatML のデータ項目から 両者の情報を結びつけるための必要な情報 を抜粋して図に示した。この枠組みでは，材 料情報（Name など）の記述する項目があり， 同レベルに Characterization という項目があ り,この項目に材料の化学組成などを記述す る。さらに，同じレベルに PropertyData（材 料特性）があり，ここに材料の各特性を記述 する．例えば，クリープ破断特性であれば， 材料特性のクリープ以下に試験応力, 破断時 間，破断延性などを記述する。

第 2 章と合わせて両者の主なデータ項目 について述べたが，ここで両者を結びつける 項目として材料特性では材料を構成する化 学成分であり，マテリアルリスク指標では， ルート項目となる物質, 材料である. 図 9 で 示したように，この化学成分は材料を構成す る合金元素を記述する項目であり，一方のマ テリアルリスク指標では物質, 材料以下の元 素記号，あるいは成分が該当し，情報連携， 共有を前提とした DB化では材料特性の化学 成分（鉄やニッケルなど）に鉄などの単体の 


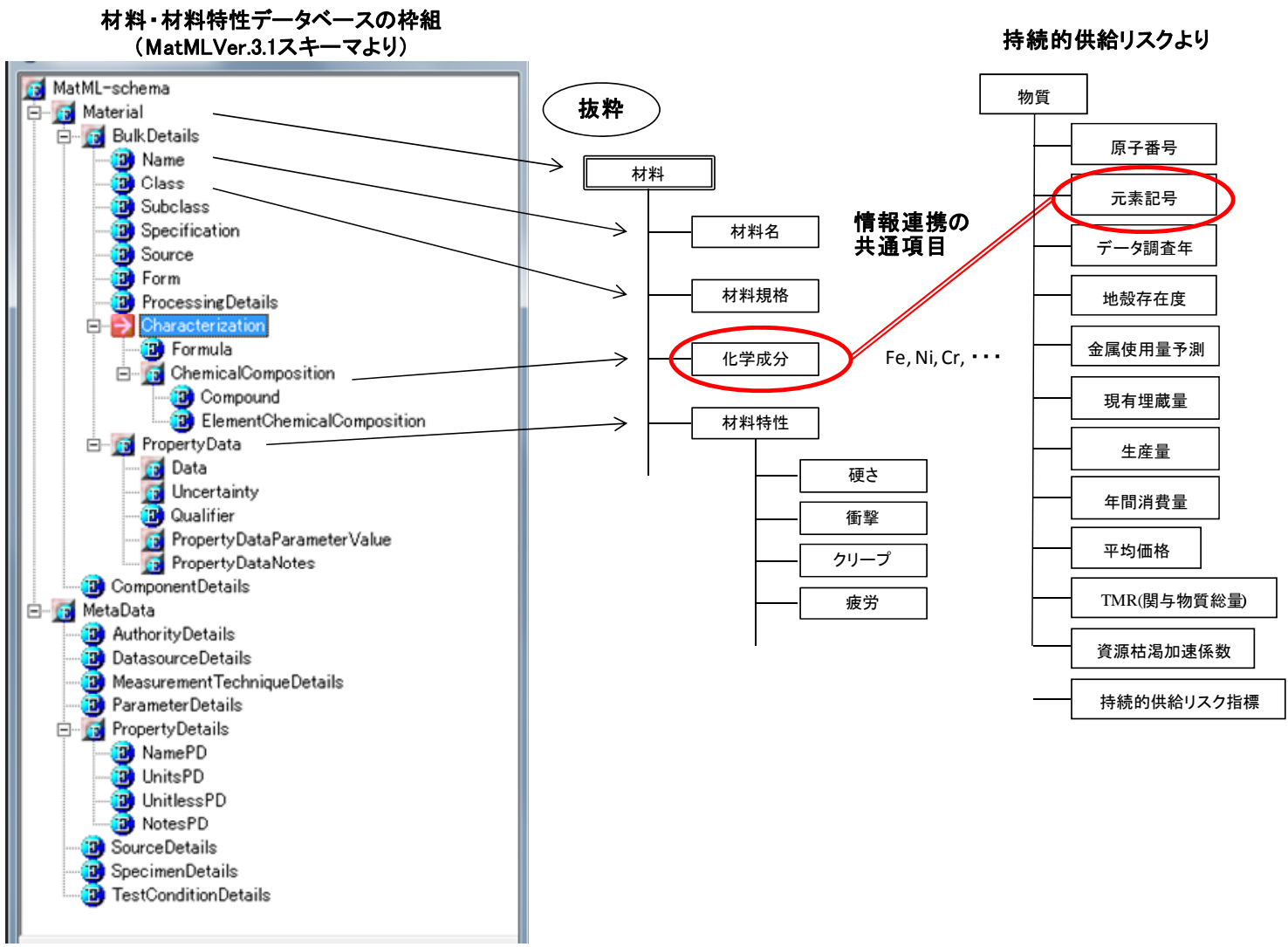

図 9 MatML をもとにした材料, 材料特性に関する主なデータ項目とリスク（持続的供給リスク） のデータ項目との繋がり（情報連携の共通項目）

マテリアルリスク情報を組み込めば両者の 情報共有が可能になる.

\section{2 各リスクと材料特性を連携するデータ 記述}

マテリアルリスク指標に関する情報や材 料特性情報などの共有, データ交換を容易に するためのデータ記述（DB 化）が必要であ る.その記述法として, 例えば, インターネ ット上の汎用的なデータ記述形式である XML をベースとした材料特性情報を記述す る MatML やMatMLを基準とした MatDB[19] などを利用することで連携が可能となる.そ の例として, MatML では, ルートの Material 以下の BulkDetails に先に述べたような材料 名や材料の化学成分（Characterization）を記 述する項目があり, 前述したように, この化
学成分の項に, 例えば, 持続的供給リスクで あれば物質（合金元素単体として）以下の項 目の組み込み，あるいは BulkDetails 以下の 項目をリスク情報 (データ項目を構造化した ひとつのモジュール(雛型)）に置き換える ことにより,一つの材料に関する特性とリス クに関する情報の結びつけ, さらに, 情報共 有が可能となる.

このような情報連携，DB 化が進めば以下 に述べるような異種領域を結びつけた新た な材料評価ができる.

以上, マテリアルリスク指標の応用として 異種領域の情報に関するデータ構造を示し, それらの情報を連携するための共通項目, デ 一タ記述について述べてきた。これらは，ひ とつの共通項目をキーワードとして必要な 情報を検索できる DB（共通形式で記述され 
た複数の DB 併合) 構築へと寄与するもので

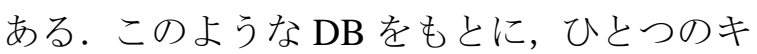
ーワードを繋がりとして異種領域の情報を 組み合わせ，新たな材料評価法，材料選択の 指針を示すことができると考える. 本報告は， 合金元素をキーワードとして, 材料の高温特 性とマテリアルリスク指標の関係を調べ, 材 料選択の方向性を示寸とともに, 新たな評価 法とするべく，以下に，その結果を述べる.

\section{4 各リスクと材料特性による材 料評価}

材料の特性とマテリアルリスク指標であ る持続的供給リスク, 環境変動リスクおよび 毒性リスクと材料の特性との関係について 調べた。これはある材料に対して目的の特性 を得るためにはどの位のリスクがともなう
かを調べたものである. 材料特性については 第 2 章（2.3 節）で述べた解析データ（引張 強さ，10 万時間強度，推定温度）を用いた。

\section{1 持続的供給リスクとの関係 TMR と特性}

TMR と材料の特性との関係を図 10(a)に示 す，両者の関係は，超合金の TMR の数值が 特出しているが，これは採掘から製品化する までの過程において合金元素の種類の多さ， 埋蔵量あるいは採掘等による物質の移動な どが要因と考える。また，超合金については ばらつきがみられるが, 材料のベース金属が TMR の少ない鉄であり, 対して TMR の多い ニッケルが起因する。ささに，温度域につい てもばらつきがあり，これは耐食性の重視あ るいは高温環境下の強度の重視などその使

持続的供給リスクと材料特性の関係
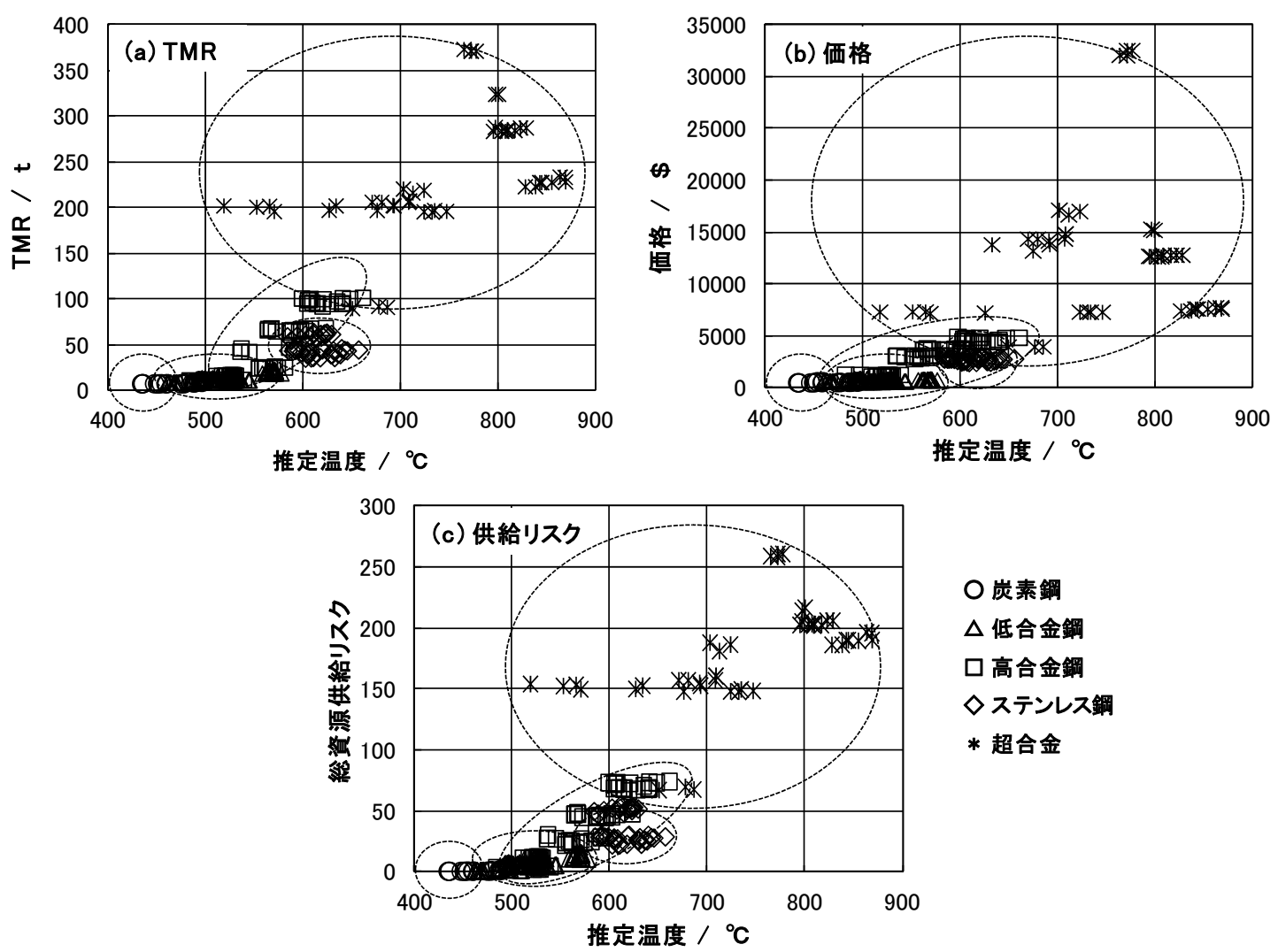

○炭素鋼

$\Delta$ 低合金鋼

$\square$ 高合金鋼

๖ステンレス鋼

* 超合金

図 10 持続的供給リスクと材料特性（推定温度）との関係 


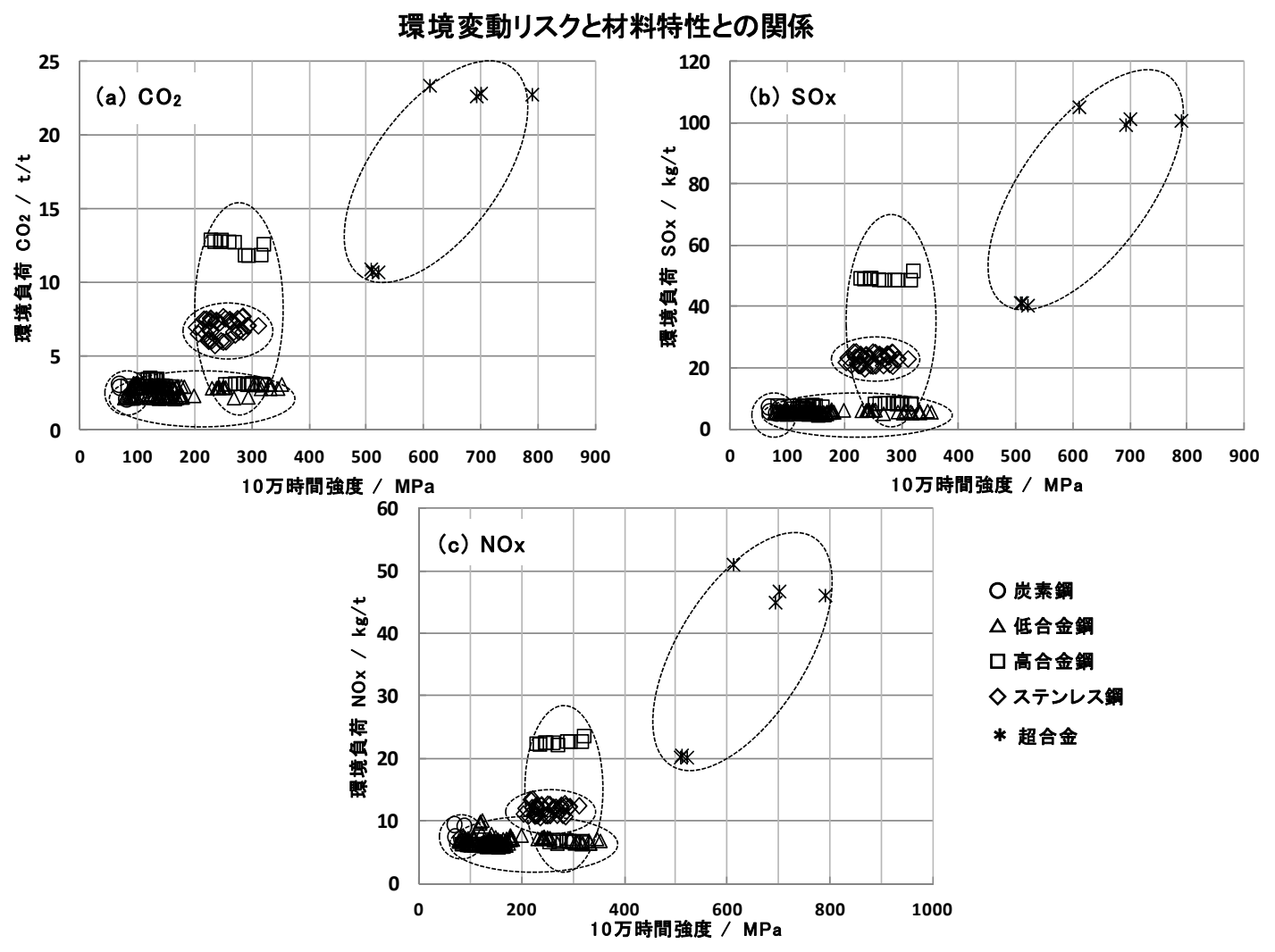

図 11 環境変動リスクと材料特性（10 万時間強度）との関係

用目的による。

\section{価格と特性}

材料を構成する合金元素の鉄, ニッケルな どの主要合金元素についてここ数年の価格 推移（算出には表 1 の平均価格を適用）をも とに材料の価格を算出し, 特性との関係を調 べ，その結果を図 10(b)に示す。両者の関係 はTMR と同様な傾向を示したが，価格につ いては安価な鉄がベースの炭素鋼や低合金 鋼は低温, 安価に位置し, 高合金鋼やステン レス鋼は中間域に, ニッケルをベースとして 合金元素の数が多い超合金は高温, 高価に位 置する

\section{供給リスクと特性}

特性と供給リスクとの関係についても他 の 2 項目と同様な傾向を示す. その結果を図 10(c)に示す. 材料別ではやはり合金元素の数 が少ない炭素鋼は供給リスクが低く, 高合金
鋼, 超合金など合金元素の数や添加量が多く なるほどその埋蔵量や資源確保により供給 リスクが高くなる。

\section{2 環境変動リスクとの関係}

図 11 は 10 万時間強度と環境負荷 ((a)CO2, (b)SOx，(c)NOx）との関係を示す。この結果 から環境負荷との関係はどれも同様の傾向 を示しているが，これは合金元素の数や製造 法などが影響し, 合金元素の数が少ない炭素 鋼や添加量が少ない低合金鋼などは環境負 荷が少なく環境への影響も少ない。一方，鉄 ベースと異なりニッケルやコバルトをベー スとする超合金は合金元素の数や合金元素 の製造過程（採掘から製品まで）が影響し環 境負荷が多くなっている.

\section{3 毒性リスクとの関係}


図 12 は毒性リスクと高温特性との関係を 示す.ここでの高温特性は, 前述したように ある材料に $100 \mathrm{MPa}$ の応力を負荷した時に に 10 万時間耐えることができる温度である. 左下に位置する炭素鋼は 400 から $500^{\circ} \mathrm{C}$ 示 し, 右側の高温域に位置する材料は超合金で ある。この図から推定温度が $700^{\circ} \mathrm{Cを}$ 超える 材料であっても毒性の強い合金元素が多く 含まれていれば，使用後の廃棄の形態（不法 投棄，野ざらし等）によっては決して望まし いものではない.また，高合金鋼あるいはス テンレス鋼は, 超合金に比べて温度が低いに もかかわらず毒性リスクが同程度となって いる要因としてやはりクロム量が多いこと があげられる。

以上, 各種材料の特性と 3 種類のリスクと の関係を調べた。その結果，両者の DB 情報 を連携することにより従来の材料特性主体 の材料評価に加え, マテリアルリスクの視点 からの情報も考慮した材料設計, 選択への指 標を示すことができた。

\section{5 マテリアルリスク指標による材料 選択}

3 種類のリスクと材料の高温特性との関係 を調べた結果をもとに最適な材料選択のた めの指針を模式図として図 13 に示す. 図 13 は, 図 10 から図 12 の結果（3 種類とも炭素 鋼から，低合金鋼，高合金鋼およびステンレ ス鋼，そして超合金の順に並べている）を模 式化したもので，いずれも右肩上がりの傾向 を示している。ここで，図 13 の特性は，持 続的供給リスクおよび毒性リスクについて は推定温度であり, 環境変動リスクについて は 10 万時間強度であることを付け加えるが， 3 種類の図の傾向は総じて各材料を構成する 合金元素の数，添加量が影響している．その

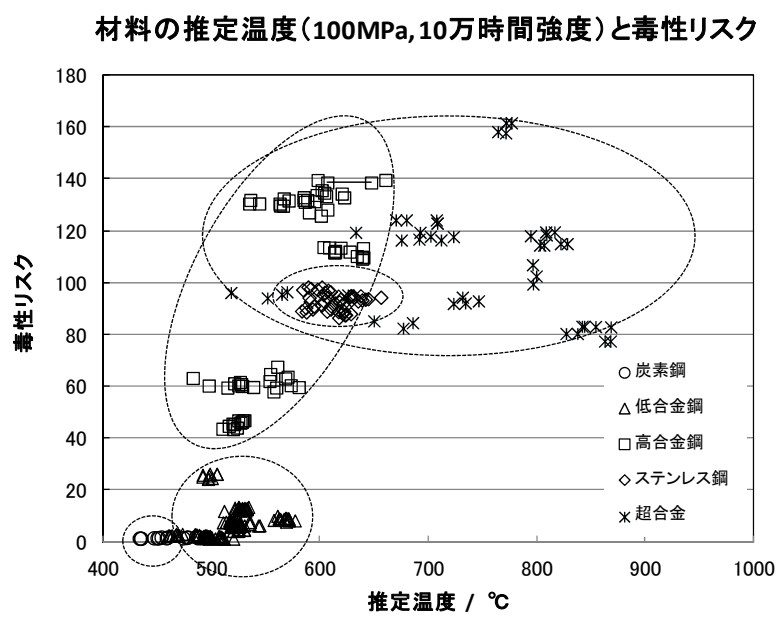

図 12 毒性リスクと材料特性（推定温度）との 関係

例として, 添加合金元素の数，量とも多い超 合金は他の材料に比べ高温特性が優れてい るが，リスクも高い。また，各材料の特性に ついては右側に位置する材料が優れている が，一方，リスクに注目すると右上に位置す る材料は, その材料に対して必要な長時間強 度あるいは耐高温を得るためには地球環境 にこれだけの影響を与えていることを示し ており, 材料製造の際にはこのような結果を 考慮する必要がある。さらに，図 13 の縦軸 の各リスクについては上側に位置する材料 はリスクが高いことを示すものであり, 総合 的な判断として右下の領域に位置する材料 の選択，開発が望まれる。言いかえれば，図 13 は，耐熱材料が，より過酷な環境で使用 されるのに必要な材料特性を得るために, よ り高合金の材料が使用されてきた.すなわち， 炭素鋼から低合金鋼，高合金鋼，ステンレス 鋼そして高合金へと, 多くの入手困難で高価 な合金元素で構成する材料が開発されてき た。資源の持続的供給，環境変動，毒性リス クの種々の因子の值が低い合金元素で構成 される材料が, 地球環境を大きく変えない環 境適合性の高い材料である。 


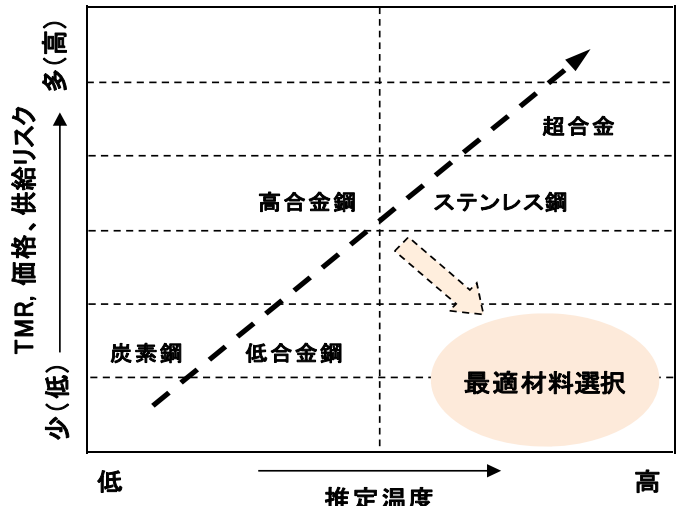

持続的供給リスクと材料特性

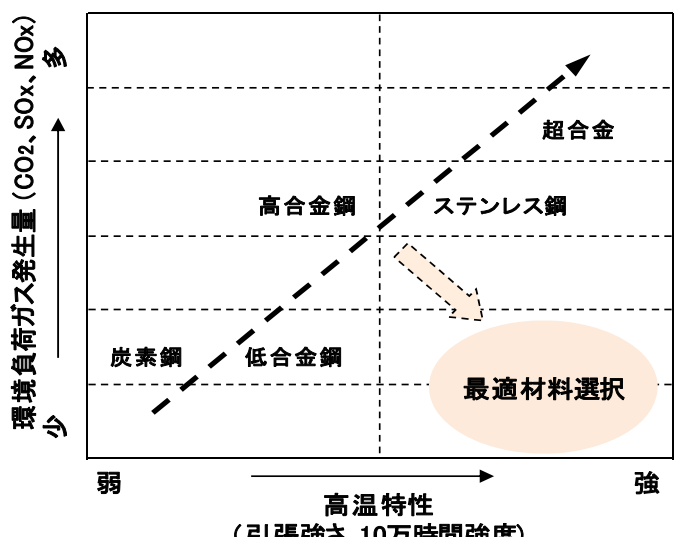

(引張強さ, 10万時間強度)

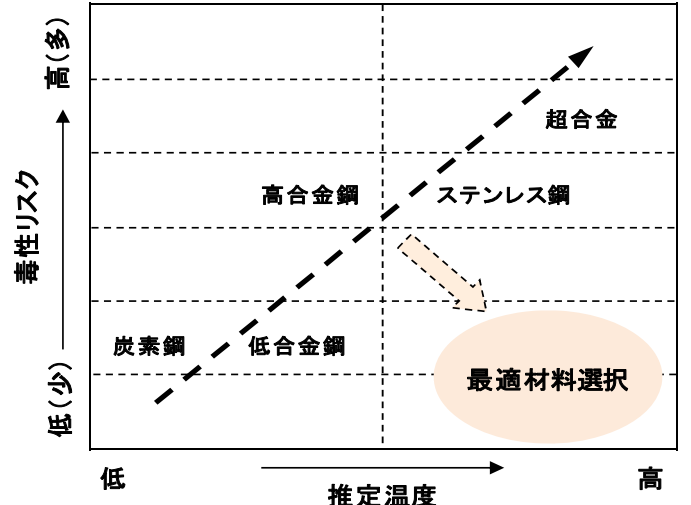

毒性リスクと材料特性

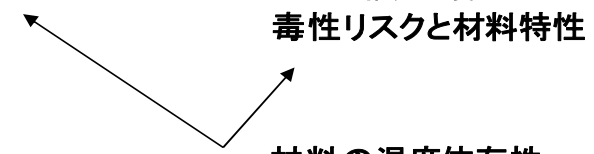

材料の温度依存性

材料の強度特性

環境変動リスクと材料特性

図 13 マテリアルリスク指標と材料特性からの材料評価・選択の方向性

\section{評価例}

ステンレス鋼は，高合金で広範囲に使用さ れている.使用される環境によって主要合金 金元素であるニッケルやクロムの合金元素 を増減したり, 微量合金元素を添加して改良 されてきた. 各種のステンレス鋼を環境適合 性と高温強度との関係を評価，検討した。環 境適合性は，3 種類のリスクのいずれの因子 でも, 安価で容易に入手可能な合金元素の量 に大きく影響される。ここでは，TMR と高 温強度の関係を図 14 に示す。高温強度は $600^{\circ} \mathrm{C} 1000$ 時間のクリープ破断強度を使用し た. 代表的なステンレス鋼である $18 \mathrm{Cr}-8 \mathrm{Ni}$ （SUS304H TB）は鉄にクロム 18\%，ニッケ ル 8\%が加えられている。この材料より TMR が高い 18Cr-12Ni-Mo（SUS316H TB）はニッ
ケル量が多くモリブデンも添加されている ので，TMR が高くなっている．18Cr-10Ni-Ti (SUS321H TB) や 18Cr-12Ni-Nb（SUS347H

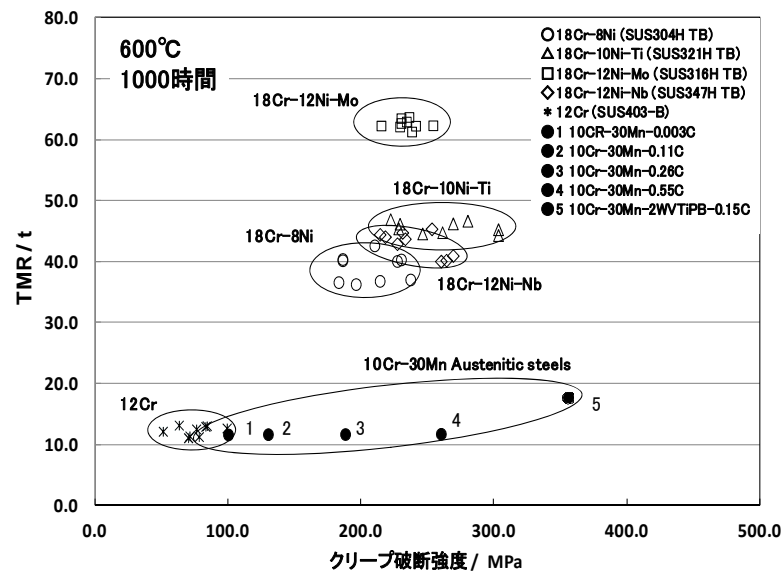

図 14 各種ステンレス鋼のクリープ破断強度 $\left(600^{\circ} \mathrm{C} ， 1000\right.$ 時間）と TMR との関係 
TB）は，チタンあるいはニオブなどが少量 添加され TMR はそれほど変わらないが，高 温強度が増加している。12Cr（SUS403-B） は, クロム 12\%のみを加えたステンレス鋼で ある。したがって，TMR は 18Cr-8Ni より少 なく, 強度も低い。図には，5種類の低誘導 放射能ステンレス鋼も評価している。このス テンレス鋼は, 中性子が照射される環境では ステンレス鋼に含まれるニッケルがコバル 卜 60 に核変換し誘導放射能を高めるので, ニッケルをマンガンすなわち入手が容易な 合金元素に置き換え, 低誘導放射能のステン レス鋼として検討，開発された材料である [20]. 5 種類のステンレス鋼の TMR と高温強 度との関係は, ニッケルをマンガンに置き換 えることによって, TMR は12Cr と同じ值で, 炭素やタングステン, バナジウムあるいはチ タンなどを少量添加することによって， TMR を大きく増加させることなく, 高温強 度を高めている。このように, 機器設計で要 求される材料の特性と各種のリスク指標と の関係を調べることによって, 持続的社会を 考慮した材料評価の第 1 歩となろう.すなわ ち, マテリアルリスク指標の多くの因子につ いて, 数值化することによって, より詳細な 材料の環境適合性の評価が可能になる.

\section{6 おわりに}

持続的社会を考慮した材料選択や材料開 発の指針得るために, これまで提唱されてい る資源の持続的供給，材料製造時の環境変動， 材料使用や廃棄時の毒性の 3 種類のリスク からなるマテリアルリスク指標と耐熱材料 の高温特性の関係を検討した。 その結果，以 下のことが明らかになった。

1 ) マテリアルリスク指標 DB を試作するた めに必要な 3 種類のリスクのデータ構造や
データ項目を明らかにし，それらをXML 記 述を行うことによって，3 種類のリスクに関 係するデータ項目の情報と耐熱材料の高温 特性との関係を容易に示すことができた。

2 ) 持続的供給リスクについては，TMR， 価格，そして供給リスクの 3 項目について材 料の特性との関係を調べたが，どの関係も炭 素鋼から低合金鋼, 高合金鋼およびステンレ ス鋼，そして超合金へと右肩上がりの傾向を 示した.これは合金元素の種類の数, 添加量 の多少が起因する.

3 ) 環境変動リスクについては, 合金元素の 数や製造法などが影響し, 合金元素の数が少 ない炭素鋼や添加量が少ない低合金鋼など は環境負荷が少なく環境への影響が少ない。 一方, 鉄ベースと異なりニッケルやコバルト をベースとする超合金は合金元素の数や合 金元素の製造過程（採掘から製品まで）が影 響し環境負荷が多くなっている.

4 ）毒性リスクについては， $700^{\circ} \mathrm{C}$ の温度環 境で 10 万時間耐える強度がある材料でも低 合金鋼などに比べるとリスクが大きい.また， 高合金鋼あるいはステンレス鋼は超合金に 比べて低温度側に位置しているがリスクが 高い要因としてクロムの添加量が影響して いる.これは表 1 のクロムの毒性リスク係数 が小さいことが要因である.

5 ) いずれのリスクにおいても，超合金のよ うに高温特性の良好な材料ほど合金元素の 種類の数と添加量が多く, 持続的供給リスク においては TMR，価格，そして供給リスク の数值がいずれも大きくなる。これは添加す る合金元素が要因であり, 強度的には優れて いるが各リスクも高いことから, 地球環境を 考慮し，さらに持続的社会を目指すためには 容易に入手可能で安価な合金元素を基にし た合金で高性能な材料開発を考える必要が 
ある。

6 ) 機器設計で要求される材料の特性と各種 のリスク指標との関係を調べることによっ て，持続的社会を考慮した材料評価の第 1 歩 となろう.すなわち, マテリアルリスク指標 の多くの因子について, 数值化することによ って，より詳細な材料の環境適合性の評価が 可能である.

\section{謝辞}

最後に, 本研究は平成 20 年度の日本学術 振興科学研究費補助金（基盤研究 B : 課題番 号 208538）の支援を受けたことを報告する。

\section{参考文献}

[1] 日本学術振興会 : 科学研究費補助金（基 盤研究 B 課題番号 208538), 環境材料設計基 準に資するマテリアルリスク指標，2008.

[2] 中島謙一他：関与物質総量（TMR）の算 定, Journal of Life Cycle Assessment, Japan, Vol.2, No.2, pp.152-158, 2006.

[3] 原田幸明：希少資源・元素の現状，まて りあ, vol.46, No.8, pp.543-548, 2007.

[4] 芳須 弘他：マテリアルリスク指標デー タベースの設計と活用，情報知識学会第 17 回年次大会, Vol.19, No. 2, pp.112-119, 2009.

[5] 芳須 弘他：資源供給情報を利用した材 料の選択指針，情報知識学会第 18 回年次大 会 Vol.20, No. 2, pp.163-170, 2010.

[6] 芳須 弘他：マテリアルリスク情報の統 合と応用, 情報知識学会第 19 回年次大会 Vol.20, No. 2, pp.163-170, 2011.

[7] 製品環境情報提供システム事務局 : 資源 枯渇性特性化係数について, 2005.

[8] 芳須 弘他：材料の環境適合性からの評 価, 日本材料学会, 材料, Vol.59, No.5, pp.354-359, 2010.
[9]（独）物質・材料研究機構元素戦略セン ター（旧エコマテリアル研究センター）： http://www.nims.go.jp/ecomaterial/ecosheet/eco sheet.htm.

[10]（独）物質・材料研究機構クリープデ ータシート : No.1〜No.41.

[11］（社）未踏科学技術協会：環境負担性 評価システム構築のための基礎調査研究, 調查報告書，（1994-1996).

[12] 経済産業省化学物質管理課： http://www.meti.go.jp/policy/chemical_manage ment/law/msds/index.html (2009 年 3 月参照). [13]（独）製品評価技術基盤機構： http://www.prtr.nite.go.jp/msds/msds.html (2009 年 3 月参照).

[14] Kohmei HALADA and Nozomu KATAGIRI : Sustainability Index of Metals, EcoBalance 2010, 2010.

[15] 山本玲子他：生体為害性合金元素と材 料,まてりあ, Vol.43, No.8, pp.639-642, 2004. [16] 物質・材料研究機構元素戦略センタ — : http://www.nims.go.jp/ecomaterial/ SMAND/database/top.html (2010 年 2 月参照). [17] 芳須 弘他：環境適合性からみた材料 の評価 - 選択指針, 配管技術, vol.53,No.4,pp32-36,2011.

[18] MatML : http://www.matml.org/ downloads/matml31v5.xsd (2011 年2 月参照). [19] MatDB，インターネット版先進金属材料 の各種材料特性ファクトデータベース： http://www.nims.go.jp/mat_info/AMM_DB/inde x.html（2011 年 3 月参照).

[20] F. Abe, T. Nod, H. Araki, S. Nakazawa : High temperature strength of simple and solute-modified $10 \mathrm{Cr}-30 \mathrm{Mn}$ austenitic steels, JOURNAL of NUCLEARMATERIALS, 191-194(1992)668-671. 